\section{Heavy metal accumulation characteristics of Nepalese alder (Alnus nepalensis) growing in a lead-zinc spoil heap, Yunnan, south- western China}

\author{
Yuebo Jing ${ }^{(1-2)}$, Hongliang Cui ${ }^{(1)}$, Tao $\mathrm{Li}^{(1)}$, Zhiwei Zhao ${ }^{(1)}$
}

\begin{abstract}
A fast-growing alder species native to the eastern Himalayas, Nepalese alder (Alnus nepalensis), has recently received considerable attention in the restoration of contaminated lands due to its significant economic benefits and ecological functions. The bioaccumulation characteristics and phytoremediation potential of naturally regenerated Nepalese alder were evaluated in a lead-zinc spoil heap located in Lancang county, Yunnan province, south-western China. Results showed that bioaccumulation factors (BFs) of $A$. nepalensis for $\mathrm{Zn}$ and $\mathrm{Pb}$ were always $>1$ in slightly contaminated soils (extractable $\mathrm{Zn}, \mathrm{Pb}$ of 4.217.9 and $3.4-13.1 \mathrm{mg} \mathrm{kg}^{-1}$, respectively) and $>1$ for $\mathrm{Cd}$ in contaminated soils (extractable Cd 0.3- $6.8 \mathrm{mg} \mathrm{kg}^{-1}$ ). By contrast, translocation factors (TFs) for $\mathrm{Zn}$ were $<1$ in all sampling plots, but $>1$ for $\mathrm{Pb}$ in soil slightly contaminated by $13.1 \mathrm{mg} \mathrm{kg}^{-1}$ extractable $\mathrm{Pb}$ and $>1$ for $\mathrm{Cd}$ in contaminated soils (extractable $\mathrm{Cd}$ 2.6-6.8 $\left.\mathrm{mg} \mathrm{kg}^{-1}\right)$. Significant positive correlations were found between heavy metals (HMs) in roots and extractable HMs in soils $(p<0.01)$ and between HMs in shoots and extractable HMs in soils $(p<0.05)$ except for $\mathrm{Cd}$. Based on the accumulation capacity revealed in this study, we suggest that A.nepalensis is a promising tree species for phytostabilization of zinc and lead in soils slightly contaminated with $\mathrm{Zn}$ and $\mathrm{Pb}$ and for phytoextraction of cadmium in Cd-polluted soil.
\end{abstract}

Keywords: Phytoremediation, Nepalese Alder, Alnus nepalensis, Metal Contamination, Bioaccumulation Factor, Translocation Factor

\section{Introduction}

Contamination of soil with zinc, lead and cadmium due to residues from metalliferous mining, smelting and other anthropic activities has attracted considerable attention in the past decade (Zhao et al. 2003). Because of the high toxicity of heavy metals (HMs) and their undegradable nature, metal pollution of soils has become one of the most serious environmental problems (Lee et al 2009). In addition, heavy metals can be transferred to the food chain from the soil and seriously affect human health (An et al. 2011). First investigated by Chaney in 1983 (An et al. 2011), phytoremediation is a pro-

mising, ecologically-friendly approach to the remediation of contaminated soil using plants to remove toxic elements from the environment or render them non-toxic (Salt et al. 1998, Suresh \& Ravishankar 2004). However, most plants are sensitive to excessive HMs in soil. In nature, only a small fraction of plants that exhibit metal tolerance or super-accumulative capacity (hyperaccumulators) can survive in toxic metal-contaminated soils, and the majority are herbaceous species with small biomasses (Sarma 2011). Woody plants or trees with developed root systems and large biomasses are especially attractive for revegetation and phytore-

(1) Laboratory of Conservation and Utilization for Bioresources and Key Laboratory of Microbial Diversity in Southwest China, Ministry of Education, Yunnan University, Kunming, 650091 Yunnan (China); (2) Yunnan Academy of Forestry, Kunming, 650201 Yunnan (China)

@ Zhiwei Zhao (zhaozhw@ynu.edu.cnl.com)

Received: Jul 20, 2013 - Accepted: Nov 20, 2013

Citation: Jing Y, Cui H, Li T, Zhao Z, 2014. Heavy metal accumulation characteristics of Nepalese alder (Alnus nepalensis) growing in a lead-zinc spoil heap, Yunnan, south-western China. iForest 7: 204-208 [online 2014-02-27] URL: http://www.sisef.it/iforest/contents/? id=ifor $1082-007$

Communicated by: Elena Paoletti mediation in metal-polluted sites (Lee et al. 2009, Capuana 2013). Additionally, exploring native plants with phytoremediation potential is a particularly important strategy, as indigenous plants are often more dependant in terms of survival, growth and reproduction under environmental stress than exotic plants (Yoon et al. 2006)

Native to Pakistan, eastern Nepal, Bhutan, northern India, south-western China, upper Myanmar and parts of Indochina, A.nepalensis is a multipurpose alder species. Characterized by a series of merits such as fast growth and nitrogen fixation, its uses include commercial timber production of moderately soft wood and charcoal feedstock. Moreover, A. nepalensis is a chief associate in various commercial timber plantations, where it not only helps to raise the nitrogen levels of fields but also acts as a pioneer species on denuded habitats with freshly exposed soils, or rocky and eroded slopes in subtropical-totemperate belts of the Himalaya (Sharma \& Ambasht 1984). Several other Alnus species have been surveyed to evaluate their phytoremediation potential for metal contaminated soils. For example, Rosselli et al. (2003) found that Alnus incana could be considered as an excluder of $\mathrm{Zn}, \mathrm{Cd}$ and $\mathrm{Cu}$. Mertens et al. (2004) found that Alnus glutinosa showed low foliar heavy metal concentrations and might therefore be suitable for phytostabilization purposes on polluted sites. Lee et al. (2009) also reported that Alnus hirsuta was a better candidate than Alnus firma for phytoremediation of HM-contaminated soils. However, there is no information about the potential of Alnus nepalensis to remediate $\mathrm{Zn}-, \mathrm{Pb}-$ and $\mathrm{Cd}$-contaminated soils.

In the present study, the metal accumulation capacity of $A$. nepalensis growing in a lead and zinc mining spoil heap in Lancang county of Yunnan province (south-western China) was evaluated. The potential application of Alnus nepalensis for phytoremediation of $\mathrm{Zn}-, \mathrm{Pb}$ - and $\mathrm{Cd}$-contaminated soils is also discussed.

\section{Materials and methods}

\section{Site description}

The sample site is approximately $3 \times 5 \mathrm{~km}$ and is located in the tailing of Munai mine in Lancang county, Yunnan province, southwestern China, where zinc and lead mining has been carried out using traditional Chinese methods for approximately 600 years (Chen et al. 1997). An A. nepalensis population has developed and is dominant in the lead-zinc spoil heap. Several shrub, grass and forb species, such as Bidens pilosa, $\mathrm{Cy}$ nodon dactylon, Ageratina adenophora, Arthraxon hispidus, Pseudocyclosorus esquirolii and Sphenomeris chinensis, are growing in addition to A.nepalensis. Five sampling 
Tab. 1 - Heavy metal contents in the soil $\left(\mathrm{mg} \mathrm{kg}^{-1}\right.$, mean $\left.\pm \mathrm{SE}, \mathrm{n}=6\right)$ from the tailing of Munai mine in Lancang county of Yunnan province, south-western China. P1 to P5 represent five sampling plots with different distances $(200 \mathrm{~m}, 500 \mathrm{~m}, 1700 \mathrm{~m}, 2800 \mathrm{~m}$ and $3800 \mathrm{~m})$ to the lead-zinc smelting facility. Different letters in the same column indicate significant differences at $\mathrm{p}<0.05$ level, according to the LSD test.

\begin{tabular}{|c|c|c|c|c|c|c|}
\hline \multirow{2}{*}{ Plot } & \multicolumn{2}{|c|}{ Zn } & \multicolumn{2}{|c|}{$\mathbf{P b}$} & \multicolumn{2}{|c|}{ Cd } \\
\hline & Total & Extractable & Total & Extractable & Total & Extractable \\
\hline P1 & $6285.3 \pm 1172.8^{a}$ & $1417.1 \pm 479.3^{\mathrm{a}}$ & $36845.5 \pm 10895.1^{\mathrm{a}}$ & $12148.0 \pm 1707.0^{\mathrm{a}}$ & $81.8 \pm 43.0^{\mathrm{a}}$ & $32.4 \pm 19.0^{\mathrm{a}}$ \\
\hline $\mathrm{P} 2$ & $4147.7 \pm 1108.3^{b}$ & $900.7 \pm 105.6^{\mathrm{b}}$ & $32323.5 \pm 17071.1^{\mathrm{a}}$ & $5544.4 \pm 1032.5^{b}$ & $35.9 \pm 17.4^{b}$ & $13.8 \pm 4.3^{\mathrm{b}}$ \\
\hline P3 & $6351.4 \pm 1565.7^{\mathrm{a}}$ & $392.9 \pm 80.9^{c}$ & $15189.7 \pm 20029.1^{b}$ & $2699.9 \pm 838.1^{\mathrm{c}}$ & $25.7 \pm 14.9^{\mathrm{bc}}$ & $6.8 \pm 1.3^{\mathrm{bc}}$ \\
\hline P4 & $415.8 \pm 206.4^{c}$ & $17.9 \pm 2.6^{\mathrm{d}}$ & $186.1 \pm 13.9^{c}$ & $13.1 \pm 1.5^{\mathrm{d}}$ & $12.0 \pm 6.3^{c}$ & $2.6 \pm 1.2^{\mathrm{c}}$ \\
\hline P5 & $212.2 \pm 56.1^{\mathrm{d}}$ & $4.2 \pm 2.8^{\mathrm{d}}$ & $40.5 \pm 36.3^{c}$ & $3.4 \pm 2.0^{\mathrm{d}}$ & $5.9 \pm 3.1^{\mathrm{d}}$ & $0.3 \pm 0.2^{\mathrm{d}}$ \\
\hline
\end{tabular}

\section{Statistical Analysis}

plots (P1-P5) were selected within the study area. The distances from sampled plots to the lead-zinc smelting facility were $200 \mathrm{~m}, 500$ $\mathrm{m}, 1700 \mathrm{~m}, 2800 \mathrm{~m}$ and $3800 \mathrm{~m}$, and these distances constituted the gradient of HM concentrations in soils involved in our study.

\section{Sample collection and analysis}

At each of the sampling plots, 6 to 10 naturally regenerated $A$. nepalensis seedlings (approximately 2-3 years old) were randomly chosen. Their roots, shoots (stems + leaves) and rhizosphere soils (depth 10-25 cm, 500 g) were collected in May 2010.

From each sampling plot, 6 plant samples were selected for analysis. The shoots (stems + leaves) and roots of the whole A. nepalensis seedlings were washed thoroughly under tap water (roots were scrubbed with a brush carefully) and then placed in an $80^{\circ} \mathrm{C}$ oven to be dried to constant weight. All dried root and shoot samples were ground separately by a mini-vegetation grinder (FZ102, Tianjing City Test Instrument Co. Ltd., China), and $0.5 \mathrm{~g}$ shoot and $0.5 \mathrm{~g}$ root powder of each sample were then subsampled by the usual method of coning and quartering. These representative subsamples were digested by $\mathrm{HNO}_{3}+\mathrm{HClO}_{4}$, and the $\mathrm{HM}$ ion concentrations were determined by flame atomic absorption spectrometry (FAAS) using a Z2000 polarized Zeeman atomic absorption spectrophotometer (Hitachi, Japan). Quantification was carried out with a calibration curve using a graded series of diluted lead (GSW08619: 0, 0.1, 0.2, 0.4, 0.8, $1.2 \mu \mathrm{g}$ $\mathrm{ml}^{-1}$ ), zinc (GSW08620: 0, 0.1, 0.2, 0.4, 0.8, $1.2 \mu \mathrm{g} \mathrm{ml}^{-1}$ ) and cadmium (GSW08612: 0 , $0.1,0.2,0.4,0.8,1.2 \mu \mathrm{g} \mathrm{ml}^{-1}$ - National Research Center for Certified Reference Materials, China). A standard reference material of poplar leaves (GBW07604 - National Research Center for Certified Reference Mate-

Tab. 2 - Pearson's correlation coefficients between extractable soil metals and total soil metals, plant metal concentrations, bioaccumulation factors (BFs) and translocation factors (TFs). $\left({ }^{*}\right)$ : $\mathrm{p}<0.05 ;(* *): \mathrm{p}<0.01$.

\begin{tabular}{llllll}
\hline Metal & $\begin{array}{l}\text { Total } \\
\text { metal }\end{array}$ & Shoot & Root & BF & TF \\
\hline Extractable $\mathrm{Zn}$ & $0.764^{*}$ & $0.940^{*}$ & $0.940^{* *}$ & -0.58 & -0.577 \\
Extractable $\mathrm{Pb}$ & $0.920^{* *}$ & $0.850^{*}$ & $0.990^{* *}$ & $-0.723^{*}$ & -0.531 \\
Extractable Cd & $0.997^{* *}$ & -0.364 & $0.983^{* *}$ & $-0.772^{*}$ & $-0.685^{*}$ \\
\hline
\end{tabular}

tion and analyzed as part of the quality control protocol (accuracies within $100 \pm 20 \%$ ). A hollow cathode lamp was operated at 4 $\mathrm{mA}$ for $\mathrm{Cd}$ and $5 \mathrm{~mA}$ for $\mathrm{Pb}$ and $\mathrm{Zn}$, and the analytical wavelengths were set at 217.0, 213.9 and $228.8 \mathrm{~nm}$ for detection of $\mathrm{Pb}$ (II), $\mathrm{Zn}$ (II) and $\mathrm{Cd}$ (II), respectively (AOAC 1984).

Rhizosphere soil samples corresponding to the above plants analyzed were also chosen for measuring the concentrations of $\mathrm{Zn}, \mathrm{Pb}$ and Cd (6 samples for each plot, a total of 30 samples were analyzed). Soil samples were air-dried, ground to fine powder in a mortar, passed through a $2 \mathrm{~mm}$ sieve, and divided into two portions by quartering. One portion was directly used for the determination of extractable soil $\mathrm{Zn}, \mathrm{Pb}$ and $\mathrm{Cd}$, and $5.0 \mathrm{~g}$ soil was weighed and put into a $100 \mathrm{ml}$ Erlenmeyer flask. Then, $50 \mathrm{ml}$ of $0.1 \mathrm{M} \mathrm{HCl}$ was added, and the solution was shaken for $2 \mathrm{~h}$ at $20{ }^{\circ} \mathrm{C}$ and filtered into a volumetric flask. Concentrations of $\mathrm{Zn}, \mathrm{Pb}$ and $\mathrm{Cd}$ were determined by FAAS as described above. The other portion was further put through a 0.15 $\mathrm{mm}$ sieve for the analysis of soil total HMs. For each soil sample, $0.2 \mathrm{~g}$ soil was digested in $5 \mathrm{ml}$ of aqua regia (ultrapure mixture of concentrated $\mathrm{HNO}_{3} / \mathrm{HCl}, 1 / 3 \mathrm{v} / \mathrm{v}$ ) in a teflon crucible and diluted with $50 \mathrm{ml}$ distilled water, and then their total HM content was analyzed by FAAS (SEPA 1997).

Translocation factors $\left(\mathrm{TF}=\mathrm{C}_{\text {shoot }} / \mathrm{C}_{\text {root }}\right.$, i.e., the ratio of HM concentration in shoot to root) were calculated to quantify the translocation of HMs from root to shoot, and bioaccumulation factors $\left(\mathrm{BF}=\mathrm{C}_{\text {shoot }} / \mathrm{C}_{\text {soil }}\right.$, i.e., the ratio of HM concentration in shoot to the extractable HMs in the soil) were calculated to quantify the HM accumulation ability of $A$. nepalensis from soil to shoot (Lorestani et al. 2011).
Departure from the normal distribution was tested for all variables by Shapiro-Wilk's test, and Levene's test was used to verify the equality of variances. HM ion concentration data were subjected to one-way ANOVA to test for differences among the five sampling plots. The threshold for statistical significance was set at $\alpha=0.05$. The relationships among extractable soil metals and total soil metals, plant metal concentrations, BF and TF were determined by Pearson's correlation analysis. Statistical analysis was carried out using the SPSS software package (version 17.0).

\section{Results}

\section{HM content in soil}

Concentrations of HMs in the soils investigated are summarized in Tab. 1. Three plots, $\mathrm{P} 1, \mathrm{P} 2$ and $\mathrm{P} 3$, were seriously polluted by $\mathrm{Zn}, \mathrm{Pb}$ and $\mathrm{Cd}$, and 2 plots, $\mathrm{P} 4$ and $\mathrm{P} 5$, were slightly contaminated, except for $\mathrm{Cd}$. Extractable HMs in the proportion of the total soil HMs ranged from 2.0 to $22.5 \%$ for $\mathrm{Zn}$, 8.5 to $17.2 \%$ for $\mathrm{Pb}$ and 4.8 to $39.3 \%$ for $\mathrm{Cd}$. In addition, a significant, positive correlation between soil total and extractable HMs was observed (Tab. 2).

\section{Accumulation and distribution of HMS in A. nepalensis}

The distribution of the metals within $A$. nepalensis is presented in Fig. 1. In general, HMs were accumulated mainly in roots, and concentrations of HMs in the roots decreased as extractable HMs in the soil decreased (Fig. 1 and Tab. 1). The highest concentration of HMs in roots occurred in sampling plot $\mathrm{P} 1$, where the concentrations of $\mathrm{Zn}, \mathrm{Pb}$ and $\mathrm{Cd}$ were 573.9, 3550.1 and $94.7 \mathrm{mg} \mathrm{kg}^{-1}$, respectively. The accumulation and distribution of $\mathrm{Zn}$ and $\mathrm{Pb}$ in shoots were similar to those in roots. The highest concentrations of $\mathrm{Zn}\left(262.8 \mathrm{mg} \mathrm{kg}^{-1}\right)$ and $\mathrm{Pb}\left(219.2 \mathrm{mg} \mathrm{kg}^{-1}\right)$ also occurred in severely polluted plot P1 and decreased as soil extractable HMs decreased. However, the accumulation of $\mathrm{Cd}$ in the shoots differed from that of $\mathrm{Zn}$ and $\mathrm{Pb}$. The highest accumulation of $\mathrm{Cd}$ occurred in $\mathrm{P} 3$, which had a moderate extractable $\mathrm{Cd}$ concentration in soil compared to the other 
plots, and the accumulation of this metal was lower in plots with higher ( $\mathrm{P} 1$ and $\mathrm{P} 2)$ and lower (P4 and P5) soil extractable Cd (Fig. 1). Furthermore, significantly positive correlation between plant metal accumulation and soil extractable HM was observed, except for $\mathrm{Cd}$ in the shoot (Tab. 2). The BFs and TFs of $A$. nepalensis for $\mathrm{Zn}, \mathrm{Pb}$ and $\mathrm{Cd}$ are given in Tab. 3. The A. nepalensis BFs for $\mathrm{Zn}$ and $\mathrm{Pb}$ were always $>1$ in $\mathrm{P} 4$ and $\mathrm{P} 5$ and $>1$ for $\mathrm{Cd}$ in $\mathrm{P} 3, \mathrm{P} 4$ and $\mathrm{P} 5$, which suggested that $A$. nepalensis acts as an accumulator of $\mathrm{Zn}$ and $\mathrm{Pb}$ in soils with lower levels of extractable HMs but not in severely polluted soils, and as a $\mathrm{Cd}$ accumulator in even moderately Cd-polluted soils. Moreover, there is a significantly negative correlation between BF and soil extractable HMs. The $\mathrm{TF}$ of A. nepalensis for $\mathrm{Zn}$ was $<1$ in all sample plots, but $>1$ for $\mathrm{Pb}$ in $\mathrm{P} 4$ and for $\mathrm{Cd}$ in $\mathrm{P} 3$ and $\mathrm{P} 4$. A negative correlation between TF and soil extractable HMs was also observed (Tab. 2).

\section{Discussion}

A considerable variation in soil and plant metal concentrations both within and between the sampling plots was observed, reflecting the heterogeneous nature of the polluted area and high individual variability within plants (Vogel et al. 2005, Unterbrunner et al. 2007). Our results indicated that metals were mainly accumulated in the roots of $A$. nepalensis, particularly in those plots with high metal concentrations (Fig. 1), which suggested strong metal retention during HM transportation from roots to shoots that might be interpreted as a mechanism that assists the plant with metal stress tolerance. Lee et al. (2009) reported that Alnus hirsuta and Alnus firma absorbed $\mathrm{Zn}, \mathrm{Pb}$, $\mathrm{Cd}, \mathrm{Cu}$ and $\mathrm{Cr}$, accumulating the metals mainly in roots, and Rosselli et al. (2003) found that Alnus incana showed a promising ability of excluding $\mathrm{Zn}, \mathrm{Cd}$ and $\mathrm{Cu}$ from its above-ground tissues. Similar results were also reported in other woody genera, such as Salix for $\mathrm{Pb}, \mathrm{Zn}, \mathrm{Cd}$ and $\mathrm{Cu}$ (Landberg \& Greger 1996, Regvar et al. 2010), Fraxinus for $\mathrm{Zn}, \mathrm{Cd}$ and $\mathrm{Cu}$ (Rosselli et al. 2003), and Eucalyptus for $\mathrm{Pb}, \mathrm{Zn}$ and $\mathrm{Cu}$ (Yang et al. 2010).
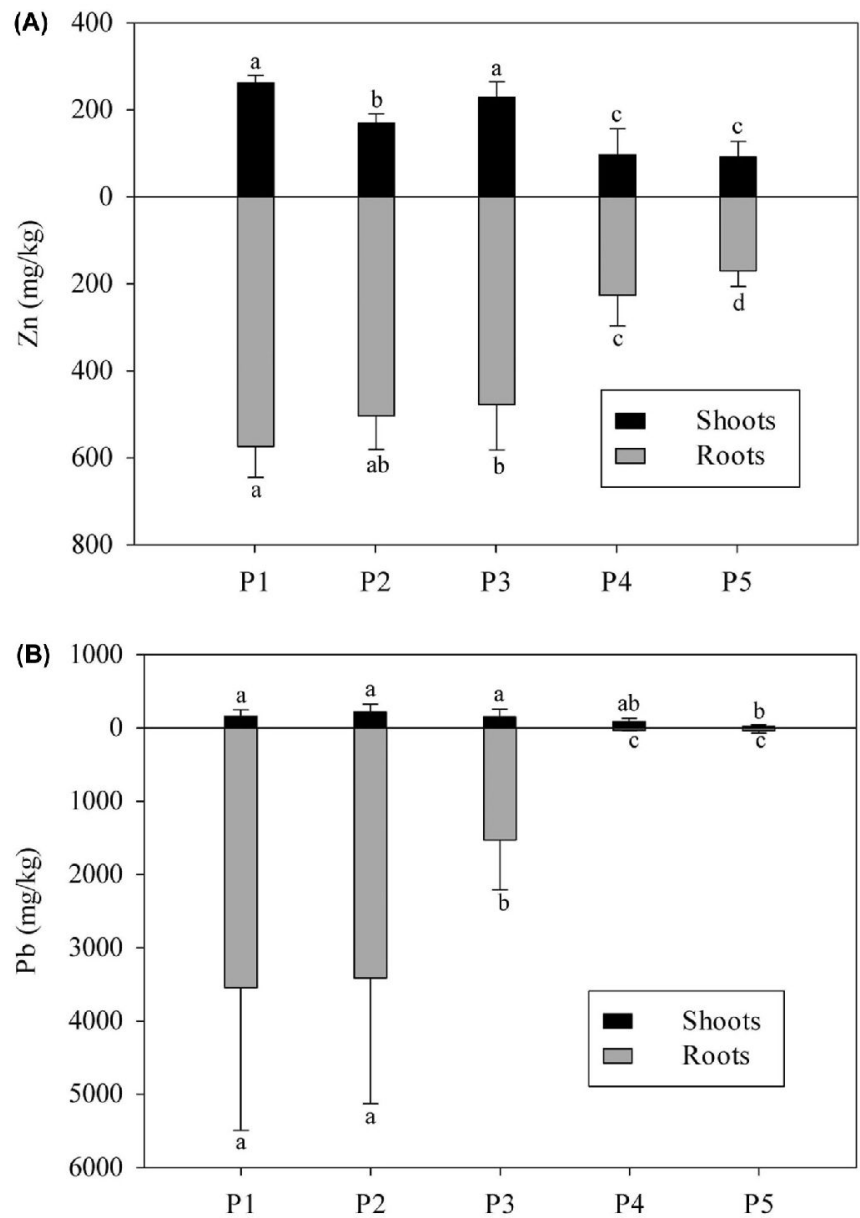

Fig. 1 - $\mathrm{Zn}(\mathrm{A}), \mathrm{Pb}$ (B) and $\mathrm{Cd}(\mathrm{C})$ accumulation in shoots and roots of A.nepalensis from the tailing of Munai mine in Lancang county, Yunnan province, south-western China. P1 to P5 are five sampling plots with different distances (200 m, $500 \mathrm{~m}, 1700$ $\mathrm{m}, 2800 \mathrm{~m}$ and 3800 $\mathrm{m})$ to the lead-zinc smelting facility. Vertical bars represent the mean $\pm \operatorname{SE}(\mathrm{n}=6)$.

Different letters above or below bars indicate significant differences among the five sampling plots analyzed at $p<0.05$ level, according to the LSD test.

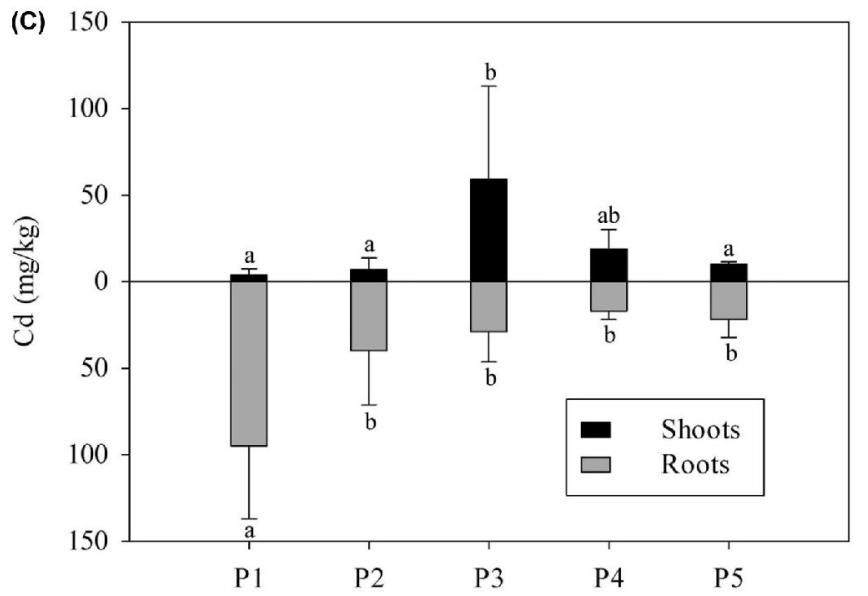

Tab. 3 - Bioaccumulation factors (BFs) and translocation factors (TFs) of $\mathrm{Zn}, \mathrm{Pb}$ and $\mathrm{Cd}$ in A.nepalensis from the tailing of Munai mine in Lancang county, Yunnan province, south-western China (mean $\pm \mathrm{SE}, \mathrm{n}=6$ ). P1 to P5 represent five sampling plots with different distances $(200 \mathrm{~m}, 500 \mathrm{~m}, 1700 \mathrm{~m}, 2800 \mathrm{~m}$ and $3800 \mathrm{~m})$ to the lead-zinc smelting facility. Different letters in the same column indicate significant differences at $\mathrm{p}<0.05$ level, according to the LSD test.

\begin{tabular}{|c|c|c|c|c|c|c|}
\hline \multirow{2}{*}{ Plot } & \multicolumn{3}{|c|}{ BF } & \multicolumn{3}{|c|}{ TF } \\
\hline & $\mathbf{Z n}$ & $\mathbf{P b}$ & Cd & Zn & $\mathbf{P b}$ & Cd \\
\hline P1 & $0.20 \pm 0.05^{\mathrm{a}}$ & $0.01 \pm 0.01^{\mathrm{a}}$ & $0.07 \pm 0.07^{\mathrm{a}}$ & $0.44 \pm 0.07^{\mathrm{a}}$ & $0.05 \pm 0.02^{\mathrm{a}}$ & $0.02 \pm 0.02^{a}$ \\
\hline $\mathrm{P} 2$ & $0.19 \pm 0.06^{\mathrm{a}}$ & $0.04 \pm 0.02^{\mathrm{a}}$ & $0.58 \pm 0.55^{\mathrm{a}}$ & $0.37 \pm 0.12^{\mathrm{a}}$ & $0.08 \pm 0.04^{\mathrm{a}}$ & $0.45 \pm 0.43^{\mathrm{ab}}$ \\
\hline P3 & $0.62 \pm 0.20^{\mathrm{a}}$ & $0.05 \pm 0.03^{\mathrm{a}}$ & $8.63 \pm 9.00^{b}$ & $0.46 \pm 0.07^{\mathrm{a}}$ & $0.11 \pm 0.11^{\mathrm{a}}$ & $1.51 \pm 0.77^{\mathrm{b}}$ \\
\hline P4 & $3.53 \pm 0.87^{\mathrm{a}}$ & $6.50 \pm 3.32^{b}$ & $8.39 \pm 4.88^{b}$ & $0.47 \pm 0.20^{\mathrm{a}}$ & $2.33 \pm 1.66^{\mathrm{b}}$ & $1.27 \pm 1.05^{b}$ \\
\hline P5 & $25.87 \pm 17.96^{b}$ & $8.85 \pm 7.58^{b}$ & $20.56 \pm 5.82^{c}$ & $0.90 \pm 0.29^{b}$ & $0.35 \pm 0.19^{c}$ & $0.54 \pm 0.15^{\mathrm{ab}}$ \\
\hline
\end{tabular}


Accumulation and exclusion are two basic strategies by which plants respond to elevated concentrations of HMs (Baker 1981). A TF $\left(\mathrm{C}_{\text {shoot }} / \mathrm{C}_{\text {root }}\right)$ greater than 1 is common in metal accumulator species, whereas the TF is lower than 1 in metal excluder species $(\mathrm{Ba}-$ ker 1981, Vogel et al. 2005). The TFs ( $\mathrm{C}_{\text {shoot }}$ $\left.\mathrm{C}_{\text {root }}\right)$ and BFs $\left(\mathrm{C}_{\text {shoot }} / \mathrm{C}_{\text {soil }}\right)$ of $A$. nepalensis for $\mathrm{Zn}$ and $\mathrm{Pb}$ were lower than 1 in soils severely polluted with $\mathrm{Zn}$ and $\mathrm{Pb}$ (P1, P2 and $\mathrm{P} 3$ ), indicating that exclusion might be its tolerance strategy. Stoltz \& Greger (2002) showed that most of the plant species growing on mine tailings exhibited restricted translocation of metals to the shoot. Rosselli et al. (2003) also reported that Alnus incana could be considered a heavy metal excluder and may have a mechanism for avoiding metal uptake by stabilizing HMs in the rhizosphere or keeping them in their roots Accumulation and translocation of $\mathrm{Cd}$ in $A$. nepalensis were somewhat complex; the $\mathrm{TF}$ and $\mathrm{BF}$ were greater than 1 in $\mathrm{P} 3$ and $\mathrm{P} 4$ which had moderate $\mathrm{Cd}$ concentrations compared to the other sampling plots, but were lower than 1 under more intensively $\mathrm{Cd}$ stressed soils (P1 and P2), which indicated that $A$. nepalensis may use different tolerance strategies under different levels of $\mathrm{Cd}$ stress. The relatively high $\mathrm{BF}$ and $\mathrm{TF}$ of $A$. nepalensis for $\mathrm{Cd}$ make it a suitable woody candidate for phytoextraction in Cd-contaminated soils. In addition, A. nepalensis accumulated relatively high concentrations of $\mathrm{Zn}$, $\mathrm{Pb}$ and $\mathrm{Cd}$ in its roots (Fig. 1), which suggested that it might be a good candidate for phytostabilization of these metals.

Phytoremediation, mainly via the mechanisms of phytoextraction and phytostabilization, is a promising and practical technology to remove HMs from polluted environments (Grabisu et al. 2002). HM hyperaccumulators, which have the ability to absorb and translocate HMs from soil to shoot, have been considered the most promising candidates in phytoextraction. Unfortunately, the majority of plants in nature are sensitive to excessive HMs in the soils. Moreover, the slow growth and small biomass of many HM hyperaccumulators have been reported to limit their application in remediating HM-polluted soils (Gaur \& Adholeya 2004). In phytostabilization, HM ions are absorbed and confined to roots and to rhizospheric soil, thus inhibiting the mobility of metal ions, restricting their leaching into groundwater and reducing metal bioavailability for entry into the food chain (Susarla et al. 2002, Conesa et al. 2006, Yoon et al. 2006). Woody plants, especially fast-growing species with large biomasses, have shown advantages and potential for application in phytostabilization (Pulford \& Watson 2003, Yoon et al. 2006). In the present study, $A$. nepalensis showed a relatively high capacity to accumulate $\mathrm{Zn}, \mathrm{Pb}$ and $\mathrm{Cd}$ in roots when growing in 5 plots with intensively polluted soils and significant $\mathrm{Cd}$ accumulation in shoots when growing in moderately contaminated soils, which suggested its potential for application in the phytoremediation of mining areas.

\section{Conclusions}

Adding to a series of desirable properties of A. nepalensis, the promising capacity of this alder species to tolerate and accumulate heavy metals was revealed for the first time in this study. A. nepalensis can accumulate relatively high concentrations of $\mathrm{Zn}, \mathrm{Pb}$ and $\mathrm{Cd}$ in its roots. The BFs for $\mathrm{Zn}$ and $\mathrm{Pb}$ that were greater than 1 indicated this plant's phytostabilization strategy and capacity in slightly contaminated soils. Remarkably, its ability to phytostabilize and phytoextract $\mathrm{Cd}$ was verified by BFs and TFs both greater than 1 , even in moderately Cd-contaminated soils. We therefore suggest that A. nepalensis is a potential candidate for use in the phytoremediation of $\mathrm{Zn}-, \mathrm{Pb}-$ and Cd-polluted soils in its indigenous range.

\section{Acknowledgments}

We thank Zhang XT, Wei YF, Zhang Y, Wang YE, Diao YH, Li XB, Wang L and Qin LP (Laboratory of Conservation and Utilization for Bioresources, Yunnan University, China) for their helps in sample collection and soil, plant samples preparation. We also thank Zhan FD (College of Resources and Environment, Yunnan Agricultural University, China) for his help and guidance in heavy metal analysis. This research was financially supported by the $\mathrm{Na}$ tional Natural Science Foundation of China (31160009; 41161083), Key Project of Applied Basic Research of Yunnan (2013FA001), Young Academic and Technical Leader Raising Foundation of Yunnan Province (2012HB006) and Technological Innovation Talents Raising Foundation of Yunnan Province (2012HB053).

Author's contribution: Yuebo Jing and Hongliang Cui contributed equally to this work.

\section{References}

An LY, Pan YH, Wang ZB, Zhu C (2011). Heavy metal absorption status of five plant species in monoculture and intercropping. Plant and Soil 345: 237-245. - doi: 10.1007/s11104-011-07751

AOAC (1984). Official methods of analysis of the Association of Official Analytical Chemists (14 ${ }^{\text {th }}$ edn). AOAC, Washington, DC, USA, pp. 344.

Baker AJM (1981). Accumulators and excluders strategies in the response of plants to heavy metals. Journal of Plant Nutrition 3: 643-654. doi: $10.1080 / 01904168109362867$

Capuana M (2013). Heavy metals and woody plants - biotechnologies for phytoremediation. iForest 4: 7-15. - doi: 10.3832/ifor0555-004
Chen SL, Peng SL, Wang ZR (1997). Structural characteristics of LaoChang $\mathrm{Ag}-\mathrm{Pb}$ orefield in LanCang, Yunnan. The Chinese Journal of Nonferrous Metals 7: 1-5.

Conesa HM, Faz A, Arnaldos (2006). Heavy metal accumulation and tolerance in plants from mine tailings of the semiarid Cartagena-La Unión mining district (SE Spain). Science of the Total Environment 366: 1-11. - doi: 10.1016/j.scitotenv.2005.12.008

Gaur A, Adholeya A (2004). Prospects of arbuscular mycorrhizal fungi in phytoremediation of heavy metal contaminated soils. Current Science 86: 528-534. [online] URL: http://www.currentscience.ac.in/Downloads/article id 086040528 0534 0.pdf

Grabisu C, Hernandez-Allica J, Barrutia O, Alkorta I, Becerril JM (2002). Phytoremediation: a technology using green plants to remove contaminants from polluted areas. Reviews on Environmental Health 17: 75-90. - doi: 10.1515/REVEH.2002.17.3.173

Landberg T, Greger M (1996). Differences in uptake and tolerance to heavy metals in Salix from unpolluted and polluted areas. Applied Geochemistry 11: 175-180. - doi: 10.1016/0883-2927 (95)00082-8

Lee DB, Nam W, Kwak YS, Cho NH, Lee SS (2009). Phytoremediation of heavy-metal-contaminated soil in a reclaimed dredging area using Alnus species. Journal of Ecology and Field Biology 32: 267-275. - doi: 10.5141/JEFB.2009.32. 4.267

Lorestani B, Cheraghi M, Yousefi N (2011). Phytoremediation potential of native plants growing on a heavy metals contaminated soil of copper mine in Iran. World Academy of Science, Engineering and Technology 53: 377-382.

Mertens J, Vervaeke P, De Schrijver A, Luyssaert S (2004). Metal uptake by young trees from dredged brackish sediment: limitations and possibilities for phytoextraction and phytostabilisation. Science of the Total Environment 326: 209 215. - doi: 10.1016/j.scitotenv.2003.12.010

Pulford ID, Watson C (2003). Phytoremediation of heavy metal-contaminated land by trees - a review. Environment International 29: 529-540. doi: 10.1016/S0160-4120(02)00152-6

Regvar M, Likar M, Piltaver A, Kugonic N, Smith J (2010). Fungal community structure under goat willows (Salix caprea L.) growing at metal polluted site: the potential of screening in a model phytostabilisation study. Plant and Soil 330: 345-356. - doi: 10.1007/s11104-009-0207-7

Rosselli W, Keller C, Boschi K (2003). Phytoextraction capacity of trees growing on a metal contaminated soil. Plant and Soil 256: 265-272. doi: 10.1023/A:1026100707797

Salt DE, Smith RD, Raskin I (1998). Phytoremediation. Annual Review of Plant Physiology and Plant Molecular Biology 49 (1): 643-668. doi: 10.1146/annurev.arplant.49.1.643

Sarma H (2011). Metal hyperaccumulation in plants: a review focusing on phytoremediation technology. Journal of Environmental Science and Technology 4 (2): 118-138. - doi: 10.3923/ 
jest.2011.118.138

SEPA (1997). Soil quality-determination of copper, zinc-flame atomic absorption spectrophotometry. Report GB/T 17138, State Environmental Protection Administration of China, Beijing, China.

Sharma E, Ambasht RS (1984). Seasonal variation in nitrogen fixation by different ages of root nodules of Alnus nepalensis plantations in the eastern Himalayas. Journal of Applied Ecology 21: 265-270. - doi: 10.2307/2403052

Stoltz E, Greger M (2002). Accumulation properties of $\mathrm{As}, \mathrm{Cd}, \mathrm{Cu}, \mathrm{Pb}$ and $\mathrm{Zn}$ by four wetland plant species growing on submerged mine tailings. Environmental and Experimental Botany 47: 271-280. - doi: 10.1016/S0098-8472(02)000 $02-3$

Suresh B, Ravishankar GA (2004). Phytoremediation - a novel and promising approach for en- vironmental clean-up. Critical Review in Biotechnology 24: 97-124. - doi: 10.1080/07388550 490493627

Susarla S, Medina VF, McCutcheon SC (2002). Phytoremediation: an ecological solution to organic chemical contamination. Ecological Engineering 18: 647-658. - doi: 10.1016/S0925-8574 (02)00026-5

Unterbrunner R, Puschenreiter M, Sommer P, Wieshammer G, Tlustos P, Zupan M, Wenzel WW (2007). Heavy metal accumulation in trees growing on contaminated sites in central Europe. Environmental Pollution 148: 107-114. - doi: 10.1016/j.envpol.2006.10.035

Vogel MK, Drobne D, Regvar M (2005). Zn, Cd and $\mathrm{Pb}$ accumulation and arbuscular mycorrhizal colonisation of penny-cress Thlaspi praecox Wulf. (Brassicaceae) from the vicinity of a lead mine and smelter in Slovenia. Environmental
Pollution 133: 233-242. - doi: 10.1016/j.envpol. 2004.06.021

Yang SX, Liao B, Li JT, Guo T, Shu WS (2010). Acidification, heavy metal mobility and nutrient accumulation in the soil-plant system of a revegetated acid mine wasteland. Chemosphere 80: 852-859. - doi: 10.1016/j.chemosphere.2010.05. 055

Joon J, Cao XD, Zhou QX, Ma LQ (2006). Accumulation of $\mathrm{Pb}, \mathrm{Cu}$, and $\mathrm{Zn}$ in native plants growing on a contaminated Florida site. Science of the Total Environment 368: 456-464. - doi: 10.1016/j.scitotenv.2006.01.016

Zhao FJ, Lombi E, McGrath SP (2003). Assessing the potential for zinc and cadmium phytoremediation with the hyperaccumulator Thlaspi caerulescens. Plant and Soil 249: 37-43. - doi: 10.1023/A:1022530217289 